\title{
THE CZECH REPUBLIC AS MARKET LEADER IN SOCIETAS EUROPAEA: HOW SUSTAINABLE ARE THE DRIVING FORCES?*
}

\begin{abstract}
Jan Lasák **
ABSTRACT

Over time, the Czech Republic has become a clear market leader in SE incorporations. For instance, in 2012, more than 55\% of all Societas Europaeas were incorporated in the Czech Republic. In recent years, the number of SE incorporations has always been substantial in the Czech Republic, which has created an interesting puzzle for both academics and practitioners. In previous research, a three-level structure of Czech SEs was identified - (i) operating SEs, (ii) "UFO SEs" and (iii) Shelf SEs. In a follow-up study prepared by Lasak and Eidenmueller, several corporate governance elements were identified as forces driving SE incorporations in the Czech Republic. My paper analyses these driving forces in the light of the development of Czech corporate governance and evaluates how sustainable these drivers for market leadership of the Czech Republic in terms of Czech SE incorporations are in the light of the recodification of Czech private law, which came into effect on 1 January 2014 and which significantly affected the motives behind the large boom in the number of SEs in the Czech Republic between 2004 and 2011/2012.
\end{abstract}

KEYWORDS: Societas Europaea, sustainability, corporate governance, regulatory arbitrage

\section{INTRODUCTION}

In the corporation's world, the creation of a new legal form is a reflection of social and economic changes in society. In the past, the formation - and especially the gradual growth - of a single European market led to the development

** This article was prepared within the project of the Grant Agency of the Czech Republic Reg. No. 19-24949S "Comparison of Czech Corporate law with the OECD Principles of Corporate Governance as an International Standard and Selected European jurisdictions.

** Jan Lasák, Palacký University Olomouc, Faculty of Law, Olomouc, Czech Republic; jan. lasak@upol.cz. 
of community expectations, which led to the demand for international companies of European descent as symbols of an integrating Europe. The process of adapting corresponding national regulations within the European Economic Community faced several difficulties, ${ }^{1}$ which is why "success", even in the form of adopting the regulation of Council (ES) No. 2157/2001 on the Status of the Societas Europaea (SE), was met with great expectations concerning the advantages that an SE was to bring for entrepreneurs throughout the individual member states of the European Union. ${ }^{2}$

The European Union called and the Czechs answered. In the course of the first few years following its entry into the European Union (2004), the Czech Republic became the market leader in terms of the incorporation of European Companies (Societas Europaea, "SE"). This puzzle became the basis of research which I carried out in 2011. The purpose of the research was to uncover the motives behind the boom in the establishment of SEs in the Czech Republic - that is to say, to evaluate the extent to which Czech entrepreneurs use this legal form and the primary reasons for why entrepreneurs choose this legal form as the framework for their business efforts.

In this article, I first summarize the results of my former research regarding the reasons for establishing SEs in the Czech Republic (within the context of regulatory arbitrage) as well as related international research focused on the development tendencies in relation to the process of establishing SEs. Then I focus on the development tendencies for establishing SEs in the Czech Republic following the completion of my research from 2011, including in the light of the recodification of Czech private law, which came into effect on 1 January 2014 and which significantly affected the motives behind the large boom in the number of SEs in the Czech Republic between 2004 and 2011/2012.

\section{THE BOOM OF SES IN THE CZECH REPUBLIC FROM 2004 TO 2011/2012}

The unification of Europe under the umbrella of the European Union, the development of a single internal market, and the mutual intertwining of national economies on the Old Continent have long been connected to the debate on regulatory arbitrage in the context of corporate law. ${ }^{3}$ Even though regulatory

\footnotetext{
Cf. Lombardo, S., Pasotti, P. The 'Societas Europaea': a Network Economics Approach. ECGI, Law Working Paper, No. 19/2004, p. 6 et seq.

2 See e.g. Enriques, L. Silence is Golden: The European Company Statute As a Catalyst for Company Law Arbitrage. Journal of Corporate Law Studies, 2004, Vol. 4, p. 77 et seq.

3 For regulatory arbitrage within the European Economic Community, see e.g. Siems, M. The Impact of the European Company (SE) on Legal Culture. European Law Review, 2005,
} 
arbitrage is frequently connected to the competition of entire legal systems, or potentially on a more general level to the quality of corporate law in its entirety, European legal literature also focused on the topic of regulatory arbitrage in relation to the existence of the SE. The SE allowed existing national companies to reincorporate under an SE with the option of changing personal status, meaning the legal system that governs the internal affairs of the relevant SE (regulatory arbitrage ex post). ${ }^{5}$

In the context of regulatory arbitrage, the enormous growth in the number of SEs in the Czech Republic took place from 2004 to 2011/2012. The fact that a relatively high number of SEs was being founded in the Czech Republic did not go unnoticed beyond the borders of the Czech Republic. For instance, Eidenmuller, Engert and Hornhuf ${ }^{6}$ carried out research focused on the initial results of using and establishing SEs within the European Union. In their work, they noticed that a surprising number of SEs were being founded in the Czech Republic. They emphasized that in the period from May 2007 to May 2008, the same number of SEs were founded in the Czech Republic as were founded in Germany in the course of three years from October 2004 to October 2007. According to Eidenmuller, Engert, and Hornhuf, there were more SEs founded in the Czech Republic at the end of 2008 than there were in Germany and most European companies in the entire European Economic Community. The situation went so far in absolute numbers that every other SE

Vol. 30, No. 435 et seq.; Enriques, L., op. cit sub 3, s. 80 et seq.; Bratton, W. W., McCahery, J. A., Vermeulen, E. P. M. How Does Mobility Affect Lawmaking? A Comparative Analysis. ECGI. Working Paper, No. 91/2008, p. 15 et seq.

4 On the "Delaware Effect" in Europe, see e.g. Sasso, L. Societas Europaea: Between Harmonization and Regulatory Competition. European Law Review, 2007, Vol. 4.

5 The admissibility of reincorporation while using the legal mode of the SE nevertheless lost its undoubted charm in the course of subsequent legislative and judicial developments. Directive No. 2005/56/ES on cross-border mergers came into effect in 2005, which permitted cross-border mergers and thereby enabled the reincorporation of national capital corporations, albeit carried out through cross-border mergers. Cross-border mergers fell under the jurisdiction of the freedom of establishment according to the European Court of Justice. With regard to C-411/03 (SEVIC Systems AG), the European Court of Justice came to the conclusion that: "Articles 43 ES and 48 ES make it impossible to enter a merger carried out by dissolving a company without liquidation and the transfer of the entire equity of this company to another company into the national commercial register in a EU member state if one of these two companies has a seat in another member state; such an entry is only possible if specific conditions are met and if the companies partaking in the merger both have a seat in the first member state.

6 Eidenmuller, H., Engert a Hornuf, L. Incorporating under European Law: The Societas Europaea as a Vehicle for Legal Arbitrage. European Business Organization Law Review, 2009, Vol. 10, p. 1 et seq. 
was either founded in the Czech Republic or Germany. Eidenmuller, Engert and Hornhuf, nevertheless, also mentioned that a large part of the Czech SEs were mere "shells," which were offered "for sale" by professional ready-made company sellers.

The question of establishing SEs and their operations within a single market was not missed by the European Commission, which issued a report on the operations and impact of the SE at the end of 2009. In the report, the European Commission stated that as of 15 April 2009 more SEs were founded in the Czech Republic than in any other member state of the European Union (137), while in neighboring Germany, only 91 SEs were founded, and only 22 SEs were founded in the Netherlands, which ranked third. ${ }^{8}$

The boom of SEs in the Czech Republic then reached an extreme level where, in 2011, 273 SEs were established in the European economic sector and only 74 of them were established in a member state other than the Czech Republic. This disparity was even greater in 2012 when out of a total of 426 SEs only 97 of them were established in a European Union country other than the Czech Republic. ${ }^{9}$ The actual reasons behind this trend, however, remained in the shadows.

\section{MOTIVES BEHIND THE RISE OF SES IN THE CZECH REPUBLIC IN 2011 AND 2012}

Since not even the aforementioned report from the EU Commission worked with any significant volume of data, my students and I conducted research at Masaryk University Law School in 2011 to uncover the specific motives behind the boom in the number of SEs founded in the Czech Republic between 2004 and 2012. While the legal regime of SEs is, to a great extent, comparable with

\footnotetext{
7 Eidenmuller, H., Engert a Hornuf, L., op. cit. sub 7, p. 20.

8 Study on the operation and the impacts of the Statute for a European Company (SE) 2008/S 144-192482 from 9 December 2009, p. 12. The European Commission analyzes three motives in the presented report, which it feels lead or could lead founders (and not only them) of Czech SEs to select this international form of corporation. As per the above, it lists fairly general reasons, such as the organizational and management structure of SEs in the form of a lower number of body members and also the option to relocate the seat to another member state in spite of the fact (as the European Commission states in the cited report) that as of the moment of processing the report in question no seat of an SE governed by Czech law had been moved abroad as of yet. Study on the operation and the impacts of the Statute for a European Company (SE) - 2008/S 144-192482 from 9 December, 2009, p. 130.

9 Source Carlson, A. SE Companies, 2017-03-31, available at http://ecdb.worker-participation.eu.
} 
the regime of a national (Czech) joint-stock company, our research focused on partial differences that may have caused entrepreneurs to make the decision to carry out their business in the form of an SE. They comprised the following:

\section{A) Image of the SE (Brand Management)}

Even though brand management is not a concept that has a significant overlap with regulatory arbitrage, we considered it possible that opting for the legal form of an SE can be a simple marketing decision as opposed to a legal decision, based on marketing and PR advantages as part of economic competition, when one considers the similarities with a joint-stock company and comparable incorporation costs. It is for this reason that we asked the entrepreneurs in our research whether brand management played a part in their decision.

\section{B) Simplification of the Internal Structure}

The regulation on SEs offered company founders the option to choose between a one-tier internal management structure (represented by an administrative board) and a two-tier internal management structure (board of directors and a supervisory board). International groups of corporations operate in many countries around the world, and thus they can use the SE to create a global and relatively unified internal management structure. ${ }^{10}$ However, the Czech legislation did not allow the founders of national joint-stock companies this option in 2011 and 2012. Since the one-tier structure allows for the existence of an SE with a single corporate body, we assumed that the management of such a company might be less expensive, which many entrepreneurs who were starting out would most likely welcome. ${ }^{11}$ The administrative board of a Czech joint-stock company must in such a case have at least three board members (Section 26 of Act No. 627/2004 Coll.).

Nevertheless, the question remained whether the one-tier structure in the context of Czech law was a simpler and more flexible management method or, in other words, whether it was more cost-effective on an operational level. The simplified internal structure could also be attractive in an SE especially in terms of a two-tier structure. It follows from Article 39 of the SE Regulation that the number of board members in an SE or the rules for designating such members within a two-tier structure is stipulated by the SE's statutes. A member state can nevertheless set a minimum and/or a maximum number of board members. The Czech legislation, however, did not stipulate a minimum

10 Cf. e.g. Lenoir, N. The Societas Europaea (SE) in Europe. A Promising Start and an Option with good prospects. Utrecht Law Review, 2008, Vol. 4, p. 17 et seq.

11 Cf. Eidenmuller, H., Engert a Hornuf, L., op. cit. sub 7, p. 10. 
or a maximum number of board members or the SE supervisory board with a two-tier structure in 2011 and 2012. Henceforth, Czech law allowed Czech SEs to have only one supervisory board member and one board member. On the other hand, Czech law required that a joint-stock company have at least three board members unless the company had a single shareholder and three supervisory board members. The simplified internal structure within an SE could have therefore been attractive if the one-tier internal management structure was implemented but also when one considered the option to have a limited number of members in the elected bodies (management boards) of an SE as part of the two-tier structure for internal management as opposed to the standard joint-stock company.

\section{C) Cross-border Mergers}

Cross-border mergers could have without a doubt played a significant role in the process of choosing to conduct business via an SE. Nevertheless, this factor slowly lost its significance, especially in relation to Directive 2005/56/ES's entry into effect and its subsequent transposition, which allowed cross-border mergers for other national capital corporations as well (joint-stock companies and limited liability companies)

\section{D) Transfer of Seat}

Just like cross-border mergers, the option of moving the company's seat also represents a factor that allows entrepreneurs to change the regulatory environment. The SE Regulation makes this possible for SEs in its Article 8. In contrast, the Czech legislature did not allow national corporations to transfer their seats in 2011 and 2012, even though it is apparent that a comparable economic effect of moving a seat (in connection to changing a personal status) was possible by carrying out a cross-border merger while using an SPV in the target EU member state.

\section{E) Participation of Employees in the Management of the Successor Company}

The decision to opt for establishing an SE may have been affected to a certain extent by the issue of employee participation in the successor company's management. When establishing an SE, the statutory body and the employees are, in general, required to enter into negotiations regarding employee participation in the successor company's management even in instances when the company has a single shareholder. Meanwhile, the final degree of employee participation in the management of the successor company could have been less advantageous to employees than it would otherwise have been apparent from Czech 
law; provisions in Article 13, Sub-section 2 of Directive 2001/86/ES, which supplements SE status regulation, excludes the use of provisions on employee participation in company bodies according to national legal regulation or established practice of the company founded. Entrepreneurs could thus opt for an SE to exclude the national codetermination modification.

\section{G) Incorporation Costs}

One might also think that another significant advantage of an SE could be that the incorporation costs (costs connected to establishing and creating an SE) would be (significantly) lower than the costs related to establishing and forming a comparable capital corporation (joint-stock company). This is not the case, however (generally speaking). Incorporation costs to establish an SE are higher than the costs for national capital corporations (e.g. the required cross-border features when establishing an SE) and clearly represent an obstacle for establishing this type of company. We gather that, in such a case, entrepreneurs would decide to conduct business under an SE only if the benefits connected to this legal form would outweigh the costs that must be paid to establish an SE.

Albeit establishing an SE could be a relatively expensive process (as compared to establishing a joint-stock company), it presents a business opportunity. Here is the moment when professional sellers of ready-made companies enter the picture. By offering already existing (shelf) SEs, these sellers significantly reduce costs which entrepreneurs would otherwise have to pay if they were to establish an SE from scratch and make them almost comparable to costs connected to establishing a joint-stock company. This again triggers the regulatory arbitrage between national (Czech) joint-stock companies and SEs.

\section{RESULTS OF THE RESEARCH ON THE DEVELOPMENT OF SES IN THE CZECH REPUBLIC IN 2011}

Our research concluded that two variables stood out behind the popularity of SEs - the image of SEs themselves and the simplification of the internal structure. ${ }^{12}$ Our results concurrently showed that the simplified internal structure was designated as the most significant motive in about $2 / 3$ of the cases. Brand management (the SE's image) played a certain role in most cases, but the simplified internal structure was by far the most significant factor.

12 Research results are summarized in detail in Lasák, J. and coll. Závod do země nikoho: 7 let evropské společnosti $v$ České republice. Obchodněprávní revue, 2011, No., p. 313 et seq. and Eidenmuller, H., Lasák, J. The Czech Societas Europaea Puzzle. Journal of Corporate Law Studies. 2012, Vol. 12, No. 2. 
Even though the respondents stated that the simplified internal structure was a significant factor for choosing the SE, only one SE selected a one-tier internal management structure. Besides, only 4 out of 220 SEs which existed at the time of our research selected a one-tier internal management structure. Even though our respondents stated that the simplified internal structure was the main reason behind their decision to establish an SE, they by far favored the two-tier internal management structure.

As provided above, under Article 39 of the SE Regulation, the number of board members in an SE or the rules for designating such members within a two-tier structure is stipulated by the SE's statutes. Even though member states were permitted to set a minimum and/or a maximum number of board members or supervisory board members of an SE, Czech legislation did not take advantage of this. Czech law allowed Czech SEs to have just one supervisory board member and one board member. To complete the picture, most companies that listed the simplified internal structure to be an important motive behind their choice to establish an SE (and implement a two-tier internal management structure), implemented an internal management system where the company had only one board member and one supervisory board member as of the date of this research.

Conversely, if the SE selects a one-tier internal management structure, Czech law requires that the SE's administrative board have at least three members. Entrepreneurs starting, therefore, faced the decision whether to create a two-tier internal management structure in the SE, where they could have one supervisory board member and one board member, or a one-tier internal management structure (not yet known in the Czech legal environment) within which Czech law requires that the company have at least three administrative board members. However, in 2011, Czech law required that a joint-stock company have at least three board members unless the company had a single shareholder, and at least three supervisory board members. The SE, therefore, allowed entrepreneurs to have a simple internal structure comprising two persons in total in the company's corporate bodies, which in its simplicity made the SE similar to a limited liability company.

Therefore, data obtained led to our conclusion that the SE brought entrepreneurs advantages by connecting the simple internal structure within the two-tier management structure where the election of one board member and one supervisory board member suffices, and concurrently, the image of the SE (brand management) - meaning that entrepreneurs considered the SE to be an instrument through which they could retain a simple internal management structure formed by two persons while at the same time enjoying the image of a joint-stock company.

The relocation of the seat and cross-border mergers appeared lower down on the list of motives for which entrepreneurs opted for an SE. The results cor- 
related with our input hypotheses where we stated that these variables would not play a dominant role in the SE selection process considering the fact that Czech national companies (joint-stock companies, limited liability companies) could carry out a reincorporation via a cross-border merger as of 1 July 2008 thanks to the transposition of Directive No. 2005/56/ES.

In many cases, our respondents reported that there were also certain regulatory (other) reasons behind their decision to choose an SE. This data collection category, therefore, showed us that some entrepreneurs opted for an SE for the reasons of having the option to choose (change) the tax regime, simpler business conduct in other member states, and potentially due to the somewhat debatable idea that their investments would be better protected within the Czech business milieu. Conversely, the issue of employee participation in the successor company's management turned out to be a relatively insignificant factor. This was even apparent in the fact that basically, no negotiations on including employees in the successor company's management took place in the course of establishing Czech SEs.

\section{THE DEVELOPMENT OF THE PROCESS OF ESTABLISHING SES IN THE CZECH REPUBLIC AFTER 2011}

An interesting trend was apparent after 2011 concerning establishing SEs in the Czech Republic as is depicted in the table below, which summarizes the number of SEs established in the European Economic Area in the years that followed:

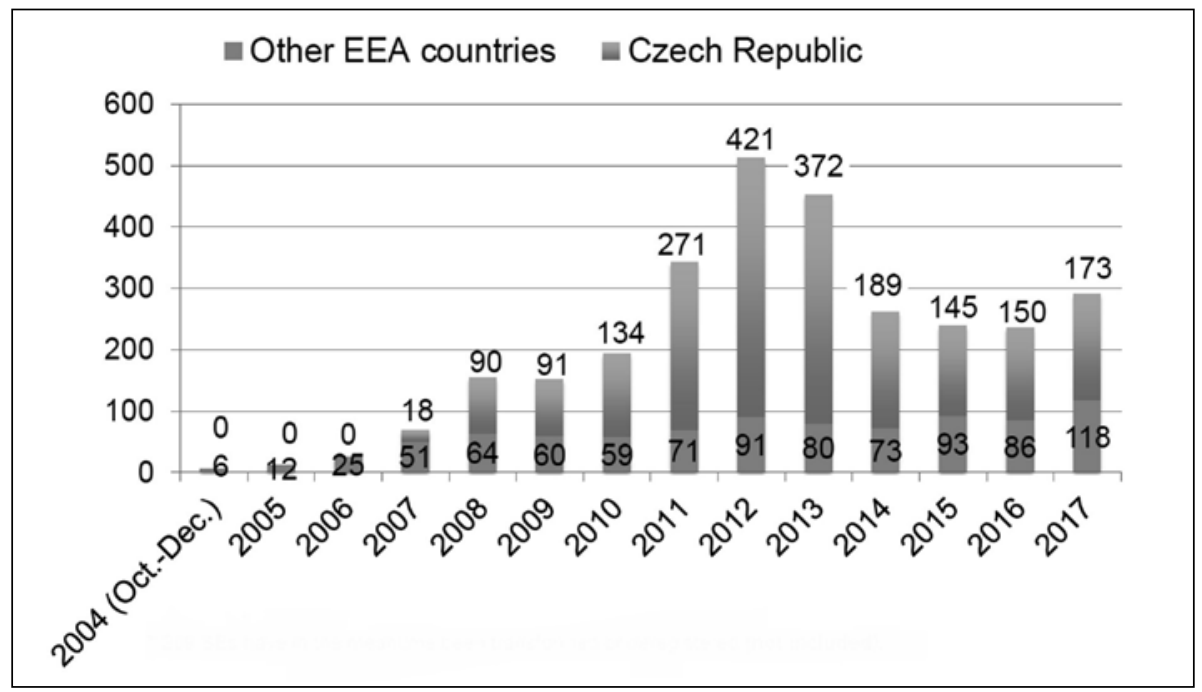

Source: Carlson, A. Societas Europaea: Latest Developments Update. (WORKERS' PARTICIPATION EUROPE NETWORK). Available at [https://www.worker-participation.eu/European-Company-SE/Facts-Figures], accessed on 06/12/2020. 
The table shows that after the peak when, which occurred in 2012 or 2013, where out of 421 SEs only 91 of them were established outside of the Czech Republic in 2012, and out of 372 SEs only 80 in 2013, there was a significant decrease in the number of SEs established in the Czech Republic, even though the Czech Republic continued to be a market leader in terms of SE establishment within the EEA. A correction therefore occurs, when between the years 2015 and 2017 about 60 SEs were established annually in the Czech Republic. What was behind this significant drop, which was first apparent in 2014, when 330 SEs and 292 SEs were established in the Czech Republic in the years 2012 and 2013, respectively? I gather that conceptual changes in the Czech legal milieu are behind this significant change as they affected the basic motives which led companies to establish SEs in the preceding years.

\section{RECODIFICATION OF PRIVATE LAW AND THE LEGAL BASIS FOR THE TRANSFORMATION OF CZECH CORPORATIONS}

The major change in the Czech corporation's law environment was brought about through the recodification of private law contained in the new Civil Code $^{13}$ and in the Corporations Act $^{14}$, which came into effect on 1 January 2014 and introduced many innovations to the Czech law. The change of the legal basis for the transfer of seat for national Czech companies, which came into effect on 1 January 2012, also may have had an impact on the number of SEs established in the Czech Republic in the years to come.

\subsection{INTERNAL STRUCTURE (CORPORATE GOVERNANCE)}

In terms of setting up the corporate governance or the internal structure of the bodies in the joint-stock company, the Corporations Act of 1 January 2014 gave entrepreneurs the option to choose between a two-tier and one-tier management structure and between the internal structures of the national (Czech) joint-stock company. As of 1 January 2014, when company founders were deciding whether to establish a joint-stock company they could choose either a two-tier model (board of directors - supervisory board) or a one-tier internal management structure.

In relation to the experience with SEs incorporated in the Czech Republic where Czech legislation (according to relevant Union regulation) allowed

13 Act No. 89/2012 Coll., the Civil Code. The number " 89 " symbolically (and intentionally) refers to 1989, when Communism fell following the Velvet revolution.

14 Act No. 90/2012 Coll., on Business Corporations and Cooperatives (“Corporations Act"). 
Czech SEs to only have one supervisory board member and one board member, the question arose regarding how suitable and desirable the current jointstock company regulation is, which required that the joint-stock company board of directors (with the exception of a situation where the company has a single shareholder), as well as supervisory board, be comprised of at least three members when the same Czech legislation allowed for SEs to have only one board member and one supervisory board member.

The Corporations Act responded by stating that as of 1 January 2014 a jointstock company's statutes could provide that the joint-stock company (with a two-tier internal management system) only has one board member and one supervisory board member. In the case of a joint-stock company with a one-tier internal management structure, the legislation even allowed for the administrative board to be composed of a single administrative board member (if the statutes of the joint-stock company so allowed), who would at the same time be the only statutory director. In other words, in terms of internal management, the national (Czech) joint-stock company had the same structure as an SE as of 1 January 2014, i.e. the board of directors and the supervisory board could have just one member or, within a one-tier system, Czech law set smaller requirements since it allowed for the administrative board to have only one member, whereby this single administrative board member could also be the statutory director (the second "required" body in the one-tier system). ${ }^{15}$

\subsection{EMPLOYEE PARTICIPATION}

Even though maintaining codetermination was at least partially considered when drafting the recodification of private law, in the end, the Corporations Act completely left this idea behind. The explanatory note to the Corporations Act concludes that codetermination, which has its roots at the end of the 19th century, i.e. from an era that was quite different economically and socially speaking, only increases transaction costs and decreases the competitive edge of local joint-stock companies.

Therefore, as of 1 January 2014, the Corporations Act canceled mandatory codetermination, and employees, therefore, lost their right to add employee representatives into the supervisory boards of joint-stock companies as opposed to SEs where employee participation is required as per the conditions set

15 The amendment to the Corporations Act, which is due to come into effect on 1 January 2021, will not affect this. This amendment stipulates that the only elected body of a joint-stock company with a one-tier internal management system will only comprise an administrative board, which can only have one member. 
forth by law. The rules of the game changed, however, as of 14 January 2017, when the obligation of a joint-stock company to implement (restore) employee participation was once again introduced for companies that had at least 500 employees (up until 31 December 2013 this was an obligation for companies with at least 50 employees). ${ }^{16}$

\subsection{TRANSFER OF COMPANY SEAT}

One of the major advantages of SEs was their option to relocate their registered office to another EEA member state. This option was basically terminated for Czech national joint-stock companies as of 1 January 2012, when the amendment to Act No. 125/2008, on Business Corporations Transformations, came into effect, which allowed national joint-stock companies (as well as other corporations) to relocate their seat within the EEA. The partial difference from the SE Regulation nevertheless was still the fact that while the regulation on seat relocation of an SE within the EEA is unified based on the SE Regulation, the national regulation on seat relocation of joint-stock companies is neither unified nor harmonized, i.e. it is necessary to rely on the mutual compatibility of the departing and incoming country in order for the relocation of the seat of a Czech joint-stock company into another jurisdiction within the EEA to be feasible (within the framework of the EU freedom of establishment).

\section{INFLUENCE OF CHANGED REGULATION ON MOTIVES BEHIND ESTABLISHING SES IN THE CZECH REPUBLIC}

As part of the research conducted in 2011, we learned that two variables stood out behind the popularity of SEs. It was the image of SEs, which still may have (rather limited role) and the simplified internal structure, mainly within the two-tier system of an SE, which allowed (and continues to allow) for the board of directors as well as the supervisory board of the SE to only have one member. Since the Corporations Act, however, made this possible for national joint-stock companies with a two-tier system as well, this "advantage" of SEs ceased to exist. National regulation on joint-stock companies further allowed for the supervisory board within a one-tier system of the joint-stock company to have (as opposed to the SE administrative board) just one member, whereby

16 Employee participation within joint-stock companies (however only in companies with a two-tier internal management structure) will remain in place even after the so-called "major" amendment to the Corporations Act, which will come into effect on 1 January 2021, and this also applies for joint-stock companies with more than 500 employees under an employment contract. 
the only administrative board member could concurrently also be the statutory director (as a second "required" body in a one-tier structure).${ }^{17}$ Even the one-tier structure of a national joint-stock company could be therefore simpler than an SE. The simplified internal structure is, therefore, no longa a factor that might motivate choosing the SE legal form.

As of 1 January 2012, another potential advantage of conducting business with an SE lost part of its significance - the potential to relocate the company's seat. Relocating a company seat across the EEA continues to be simpler for SEs than for a national joint-stock company, since the SE Regulation contains unified regulation on such relocations within the EEA, while the legal regulation on relocating the seat of national (joint-stock) companies across Europe is not unified or harmonized. Therefore, national joint-stock companies may run into certain difficulties as a result of the potential incompatibility of different legal systems. The simpler relocation of an SE's seat continues to be, even to a much lesser degree, an advantage for conducting business in the form of an SE, especially if the nature of the business of the company does not rule out relocating the seat (typically in the case of online businesses). On the other hand, however, even according to our research from 2011, the option of a simpler relocation of a seat was not the most significant motive behind establishing an SE in the Czech Republic. It can therefore be expected that its significance will continue to play only a limited role even when one considers the potential for reincorporating a national joint-stock company using cross-border mergers, which are permitted for SEs as well as for national joint-stock companies.

Considering the only temporary change to the legal framework for codetermination, when this was first taken out of Czech law in 2014 only to be re-implemented at the start of 2017 into the Czech legal system, I gather that this short incursion had only a minor influence on the potential for establishing SEs in the Czech Republic, also when one considers the fact that no negotiations on including employees into SE management were taking place when incorporating and selling ready-made SEs.

One factor which can still have an influence on the relatively high number of SEs established in the Czech Republic is the existence of a large market with ready-made companies. SEs became a part of the standard offer for founders on sellers' "price lists" and therefore these sellers of ready-ready companies had no immediate reason to stop offering ready-made SEs when they became a natural part of the Czech business milieu. The drop in their sales (and follow-up incorporations by professional sellers of ready-made companies) can,

17 Meanwhile, the statutory director ceases to exist altogether as a separate body of a jointstock company with a one-tier internal management system as of 1 January 2021. 
however, be explained by the fact that, to a certain extent, the advantages offered by SE legal regulation prior to the effective date of private law recodification (1 January 2014) were, to a not insignificant level, eliminated within Czech national law.

\section{CONCLUSION}

Between 2007 and 2013, the Czech Republic became a market leader in SE establishment, which led to research aimed at determining what factors affected such dominance in the Czech Republic. To the best of my knowledge, however, this research was conducted in 2011 for the last time while after 2014; we saw an interesting drop in the number of SEs established in the Czech Republic. Considering the research conducted in 2011, we can conclude that two major advantages of SEs were eliminated in subsequent years. Effective as of 1 January 2012, Czech law modified the options for national corporations (including joint-stock companies) to relocate their seat within the EEA. In 2014, the Czech legislators unified the basic personal conditions for creating a two-tier internal management system for joint-stock companies and SEs, while according to research from 2011, this was the main motive leading to the major boom in SEs being established in the Czech Republic.

The fact that the Czech Republic continues to be the market leader in terms of SE establishment, albeit to a lesser extent, may be explained by the fact that some of the motives which were identified continued to exist even after the legislative changes took place (e.g. brand management and easier seat relocation) and in part also due to fact that professional ready-made company sellers have had no immediate reasons to stop offering ready-made SE companies (and of course, incorporating new ones) as SEs became a part of the Czech market.

\section{LITERATURE}

1. Bratton, W. W., McCahery, J. A., Vermeulen, E. P. M. How Does Mobility Affect Lawmaking? A Comparative Analysis. ECGI. Working Paper, No. 91/2008 -DOI: https://doi.org/10.2139/ssrn.1086667

2. Carlson, A. Societas Europaea: Latest Developments Update. (WORKERS' PARTICIPATION EUROPE NETWORK). [https://www.worker-participation. eu/European-Company-SE/Facts-Figures], accessed on 06/12/2020

3. Eidenmuller, H., Engert a Hornuf, L. Incorporating under European Law: The Societas Europaea as a Vehicle for Legal Arbitrage. European Business Organization Law Review, 2009, Vol. 10, No. 1, p. 1 et seq

-DOI: https://doi.org/10.1017/S1566752909000019 
4. Eidenmuller, H., Lasák, J. The Czech Societas Europaea Puzzle. Journal of Corporate Law Studies. 2012, Vol. 12, No. 2, p. 237 et seq.

-DOI: https://doi.org/10.5235/JCLS.12.2.237

5. Enriques, L. Silence is Golden: The European Company Statute as a Catalyst for Company Law Arbitrage. Journal of Corporate Law Studies, 2004, Vol. 4, p. 77 et seq.

-DOI: https://doi.org/10.1080/14735970.2004.11419914

6. Lasák, J. and coll. Závod do země nikoho: 7 let evropské společnosti v České republice. Obchodněprávní revue, 2011, No., p. 313 et seq.

7. Lombardo, S., Pasotti, P. The 'Societas Europaea': a Network Economics Approach. ECGI, Law Working Paper, No. 19/2004

-DOI: https://doi.org/10.2139/ssrn.493422

8. Sasso, L. Societas Europaea: Between Harmonization and Regulatory Competition. European Law Review, 2007, Vol. 4, p. 159 et seq.

9. Siems, M. The Impact of the European Company (SE) on Legal Culture. European Law Review, 2005, Vol. 30, No. 435 et seq.;

10. Lenoir, N. The Societas Europaea (SE) in Europe. A Promising Start and an Option with good prospects. Utrecht Law Review, 2008, Vol. 4, p. 17 et seq.

-DOI: https://doi.org/10.18352/ulr.57 
